\title{
The Effect of Oxygen on the Growth and Mannitol Fermentation of Streptococcus mutans
}

\author{
By MASAKO HIGUCHI \\ Department of Oral Biochemistry, Tohoku University School of Dentistry, Sendai 980, Japan
}

(Received 29 September 1983; revised 16 December 1983)

The effects of oxygen on growth and mannitol fermentation of eight strains of Streptococcus mutans were compared under aerobic and strictly anaerobic conditions. The growth of three strains was severely inhibited by oxygen, whereas the others were oxygen-tolerant. The growth of two of the oxygen-tolerant strains was significantly enhanced by oxygen. The activities of superoxide dismutase and NADH oxidase in extracts from aerobically grown bacteria showed a positive correlation with the growth rate under aerobic conditions. The activities of these enzymes in oxygen-sensitive strains grown aerobically were as small as those in anaerobically grown cultures. Moreover, the enzyme activities increased during aeration of anaerobically grown oxygen-tolerant strains, but not in oxygen-sensitive strains. In all strains, oxygen changed mannitol catabolism from heterolactic to homolactic fermentation. It was concluded that oxygen-tolerance of $S$. mutans is dependent on the ability of strains to induce NADH oxidase and superoxide dismutase.

\section{INTRODUCTION}

A lactic acid bacterium, Streptococcus mutans, has been implied as a causative agent of dental caries (Krasse et al., 1968; Woods, 1971; Shklair et al., 1972). The important characteristics distinguishing it from other oral streptococci include its ability to synthesize the adhesive and highly branched glucan, mutan, from sucrose and to utilize mannitol and sorbitol as a primary energy source for growth (Carlsson, 1967; Guggenheim, 1968). Although the bacterium is considered as a facultative anaerobe, the strains classified as serotype $a$ require an atmosphere of low oxygen content for growth (Coykendall, 1977). However, growth of the neotype strain ( $S$. mutans NCTC 10449) is enhanced by oxygen and retarded by anaerobiosis, particularly when the cells are grown on mannitol (M. Higuchi, unpublished observations). Recently, Abbe et al. (1982) reported that the oxygen-sensitive enzyme pyruvate formate-lyase regulates mannitol metabolism of $S$. mutans JC2.

In the present study, the effects of aerobiosis and anaerobiosis on the growth and on activities of several enzymes involved in mannitol catabolism and oxygen defence of various strains of $S$. mutans have been explored. The results show that the oxygen-tolerance of $S$. mutans is not directly correlated with the serotype (Bratthall, 1969; Perch et al., 1974) nor with the four subspecies (Coykendall, 1974), but that growth response to oxygen is correlated with the ability of the strains to induce NADH oxidase and superoxide dismutase.

\section{METHODS}

Organisms and culture medium. The eight strains of $S$. mutans used in this study together with their serological group are listed in Table 1. They were maintained monthly by transfer on blood agar and mitis-salivarius agar plates. All strains were grown in a broth containing $(\%, w / v)$ : trypticase peptone (BBL), $1 \cdot 0$; yeast extract (Daigo Chemical Co., Osaka, Japan), $0 \cdot 2 ; \mathrm{NaCl}, 0 \cdot 2 ; \mathrm{K}_{2} \mathrm{HPO}_{4}, 0 \cdot 3 ; \mathrm{KH}_{2} \mathrm{PO}_{4}, 0 \cdot 2 ; \mathrm{K}_{2} \mathrm{CO}_{3}, 0 \cdot 1 ; \mathrm{MgSO}_{4} .7 \mathrm{H}_{2} \mathrm{O}, 0 \cdot 01$; $\mathrm{MnSO}_{4} \cdot 4 \mathrm{H}_{2} \mathrm{O}, 0.002$; mannitol, 1.0 (TYM medium, pH 7.0). The medium was sterilized at $121^{\circ} \mathrm{C}$ for $15 \mathrm{~min}$. Catalase and pyruvate were separately sterilized by filtration. 
Table 1. Strains of S. mutans used

$\quad$ Strain
FIL
PK 1-EB1
BHT
FA1
NCTC 10449
MT8148
6715
PK 1-M

Serotype*

$\begin{array}{ll}a & \text { cricetus } \\ b & \text { rattus } \\ b & \text { rattus } \\ b & \text { rattus } \\ c & \text { mutans } \\ c & \text { mutans } \\ g & \text { sobrinus }\end{array}$

* Classified by Bratthall (1969); Perch et al. (1974).

† Proposed by Coykendall (1974).

\section{Reference}

Yamada et al. (1976)

Higuchi et al. (1973)

Zinner \& Jablon (1968)

Fitzgerald et al. (1960)

Edwardsson (1968)

Hamada et al. (1981)

Iacono et al. (1975)

Higuchi et al. (1973)

Growth conditions. For aerobic growth the organisms were cultured either in a $500 \mathrm{ml}$ flask containing $100 \mathrm{ml}$ medium under air with vigorous shaking (120 r.p.m.) or in a 21 flask containing $500 \mathrm{ml}$ medium, mixed vigorously with a magnetic stirrer and in a flow of air of more than $301 \mathrm{~h}^{-1}$.

For strictly anaerobic growth, special care was taken. The organisms were cultured in a Pyrex glass bottle $(500 \mathrm{ml})$ or a test tube $(12 \times 100 \mathrm{~mm})$ with a screw cap in an anaerobic glove box under an atmosphere of $80 \%$ nitrogen, $10 \%$ hydrogen and $10 \%$ carbon dioxide (Hirasawa Works, Tokyo, Japan). All anaerobic media were prereduced for at least $24 \mathrm{~h}$ before inoculation to ensure strict anaerobiosis. All cultures were pre-adapted in TYM medium, inoculated with approximately $10^{7}$ cells $\mathrm{ml}^{-1}$ and maintained at $35^{\circ} \mathrm{C}$. The dry weight of the cells was estimated from the $A_{660}$ and calibration curves.

Enzyme induction. Anaerobically grown organisms from the mid-exponential phase were harvested by centrifugation $(21000 \mathrm{~g}, 10 \mathrm{~min})$, resuspended in $500 \mathrm{ml}$ TYM medium and then divided into $100 \mathrm{ml}$ volumes in five $500 \mathrm{ml}$ flasks under anaerobic conditions. One flask was kept for $2 \mathrm{~h}$ at $35^{\circ} \mathrm{C}$ in an anaerobic glove box, after which the cells were sedimented by centrifugation $(21000 \mathrm{~g}, 10 \mathrm{~min})$, washed three times with $50 \mathrm{~mm}$-potassium phosphate buffer ( $\mathrm{pH} 7 \cdot 0$ ) and kept in ice-water under anaerobic conditions. Another flask was placed aerobically in an ice-bath to arrest enzyme induction. The other three flasks were stoppered with cotton plugs and incubated at $35^{\circ} \mathrm{C}$ under air with vigorous shaking (120 r.p.m.). After 30,60 and 120 min incubation, the flasks were chilled in ice-water and the bacteria were sedimented and washed as described above. The pellets were kept in ice-water. These procedures were carried out under air. All sedimented cells were disrupted by sonication within $1 \mathrm{~h}$ of harvesting.

Preparation of extracts. The organisms, grown to late-exponential phase, were harvested by centrifugation $(21000 \mathrm{~g}, 10 \mathrm{~min})$ at $4{ }^{\circ} \mathrm{C}$ and were subjected to the following procedures, which were carried out under strictly

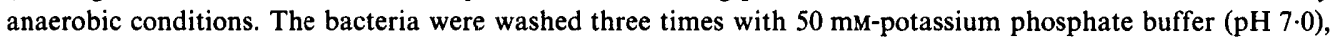
sealed tightly and stored at $-20^{\circ} \mathrm{C}$. The pellets were thawed in 50 mM-potassium phosphate buffer $(\mathrm{pH} 7 \cdot 0 ; 4 \mathrm{ml}$ per $\mathrm{g}$ wet weight), and disrupted by sonication using a Kubota Insonator (Model 200M, Kubota Co., Tokyo, Japan) at $200 \mathrm{~W}$ for $15 \mathrm{~min}$, at $0^{\circ} \mathrm{C}$. Following centrifugation $(25000 \mathrm{~g}, 30 \mathrm{~min})$ the supernatant fluids were used as crude extracts. To remove contaminating substrates and metal ions, particularly manganese, the crude extracts were dialysed against 4 litres $50 \mathrm{~mm}$-potassium phosphate buffer containing $0 \cdot 1 \mathrm{~mm}$-EDTA for $18 \mathrm{~h}$ at $4{ }^{\circ} \mathrm{C}$ under air before assay of NADH oxidase and superoxide dismutase.

Assay of NADH oxidase, lactate dehydrogenase (EC 1.2.1.22), mannitol-1-phosphate dehydrogenase (EC 1.1.1.17) and alcohol dehydrogenase (EC 1.1.1.1). These enzyme activities were measured spectrophotometrically by monitoring the oxidation or reduction of $\mathrm{NAD}(\mathrm{H})$ in the reaction mixtures $(1 \mathrm{ml})$ at $340 \mathrm{~nm}$. One unit of enzyme activity was defined as the amount of enzyme (mg protein) which catalysed the oxidation or reduction of $1.0 \mu \mathrm{mol} N A D(H) \mathrm{min}^{-1}$. NADH oxidase activity was estimated by measuring the oxidation rate of NADH in the presence of oxygen. The reaction mixtures were as follows. NADH oxidase: 50 mM-potassium phosphate buffer (pH 7.0), $0 \cdot 1 \mathrm{mM}$-NADH and the extract. Lactate dehydrogenase: $65 \mathrm{~mm}$-potassium phosphate buffer (pH 6.5), 0.1 mM-NADH, $20 \mathrm{mm-sodium} \mathrm{pyruvate,} 10 \mathrm{~mm}$-fructose 1,6-bisphosphate and the extract. Mannitol-1phosphate dehydrogenase : 2 mM-fructose 6-phosphate, $0.1 \mathrm{~mm}-\mathrm{NADH}, 100 \mathrm{~mm}$-Tris/HCl buffer (pH 8.5) and the extract. Alcohol dehydrogenase activity was assayed by the method of Brown \& Patterson (1973).

These assays were carried out aerobically at $25^{\circ} \mathrm{C}$.

Assay of superoxide dismutase (EC 1.15.1.1). Superoxide dismutase activity was assayed by the xanthine oxidase/cytochrome $c$ method (Vance \& Keele, 1972). One unit of superoxide dismutase activity was defined as the amount (mg protein) which gave a $50 \%$ decrease in the rate of reduction of cytochrome $c$.

Assay of pyruvate formate-lyase (EC 2.3.1.54). This activity was estimated by a modification of the method of Yamada \& Carlsson (1976). The reaction mixture contained $100 \mathrm{~mm}$-potassium phosphate buffer (pH 7.0), $20 \mathrm{mM}$ sodium pyruvate, $20 \mathrm{~mm}$-sodium oxamate, $0.05 \mathrm{~mm}$-CoA, $2.0 \mathrm{~mm}$-dithiothreitol and 0.02 units phosphoacetyl- 
transferase. The amount of acetylphosphate produced in the reaction at $35^{\circ} \mathrm{C}$ for $15 \mathrm{~min}$ under anaerobic conditions was estimated by the method of Lipman \& Tuttle (1945). One unit of pyruvate formate-lyase activity was defined as the amount of enzyme (mg protein) which produced $1.0 \mu \mathrm{mol}$ acetylphosphate $\mathrm{min}^{-1}$.

Estimation of oxygen consumption and hydrogen peroxide production. Oxygen consumption and hydrogen peroxide production by extracts were estimated polarographically at $37^{\circ} \mathrm{C}$ with an oxygen monitor (model 53; Yellow Springs Instruments Co., Yellow Springs, Ohio, USA) by the method of Carlsson et al. (1983). The electrode was calibrated by the phenylhydrazine/ferricyanide method (Misra \& Fridovich, 1976).

Estimation of acetate, formate and lactate in fermentation products. Carboxylic acids in the culture supernatant were analysed by an auto carboxylic acid analyser (model S-14; Seishin Pharmaceutical Co., Chiba, Japan) with a detection system based on 2-nitrophenylhydrazone formation according to the method of Kasai et al. (1977). Formate was also determined spectrophotometrically by the method of Sawicki et al. (1961).

Estimation of ethanol in fermentation products. Ethanol in the supernatant fluids was measured by a gas-liquid chromatograph (model GC-7A; Shimazu Co., Tokyo, Japan) on a Chromosorb 101 column at $150{ }^{\circ} \mathrm{C}$ using a flame ionization detector.

Other analytical procedures. Protein was determined by the biuret method (Gornall et al., 1949) using bovine serum albumin solution as standard.

Chemicals. NAD, NADH, Coenzyme A (CoA), L-lactate dehydrogenase and xanthine oxidase were obtained from Boehringer; ferricytochrome $c$, fructose 6-phosphate, phosphoacetyltransferase, catalase and sodium pyruvate were from Sigma; and xanthine from cow's milk was from Nakarai Chemicals Co., Tokyo, Japan.

\section{RESULTS}

\section{Effect of oxygen on the growth of $S$. mutans on mannitol}

When eight strains of $S$. mutans were grown under aerobic and strictly anaerobic culture conditions, three distinct patterns of growth response to air were observed. Strains FIL, MT8148 and PK 1-M grew well on mannitol under strictly anaerobic conditions $(1.5$ to $3 \mathrm{~h}$ doubling time), whereas under aerobic conditions the growth was severely inhibited (10 to $12 \mathrm{~h}$ doubling time) (Fig. $1 a$ ). In contrast, the other five strains were oxygen-tolerant. Two of them, strains NCTC 10449 and PK 1-EB1 (type I) grew better under aerobic conditions (1.5 to $2 \mathrm{~h}$ doubling time) than under strictly anaerobic conditions ( 3.5 to $4.5 \mathrm{~h}$ doubling time) (Fig. $1 \mathrm{~b}$ ), while three strains, BHT, FA1 and 6715 (type II) grew better under anaerobic conditions ( 2 to $3.5 \mathrm{~h}$ doubling time) than under aerobic conditions ( 4.5 to $5.5 \mathrm{~h}$ doubling time) (Fig. $1 \mathrm{c}$ ).

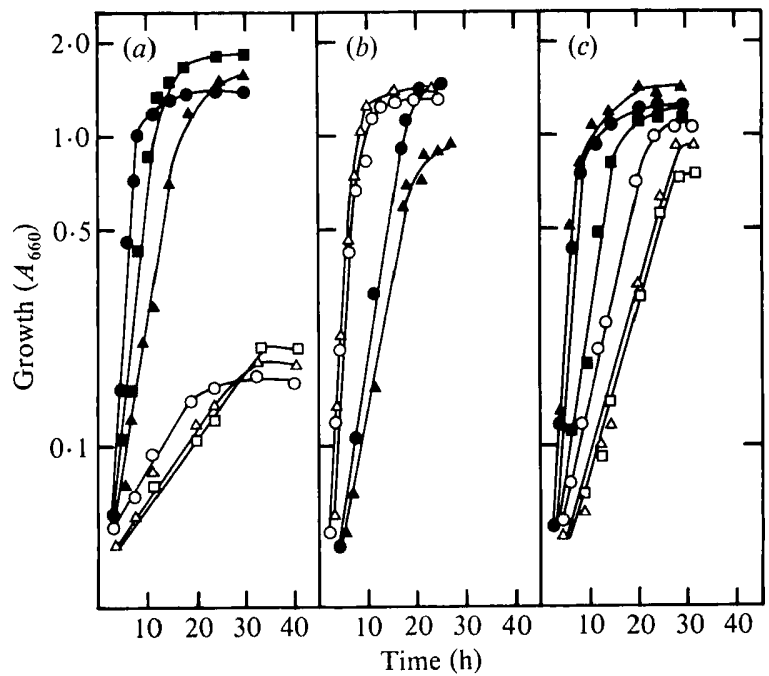

Fig. 1. Effect of oxygen on the growth of $S$. mutans on mannitol cultures. Eight strains of $S$. mutans were grown at $35^{\circ} \mathrm{C}$ in TYM medium containing $1 \%$ mannitol under aerobic and anaerobic growth conditions as described in Methods. Open symbols show aerobic growth and filled symbols show anaerobic growth. (a) Oxygen-sensitive strains: FIL $(\triangle, \Delta)$. MT8148 $(\square, \square) ;$ PK 1-M $(O, O) .(b)$ Oxygen-tolerant strains (Type I) : NCTC $10449(\mathrm{O}, \boldsymbol{O})$; PK 1-EB1 $(\triangle, \boldsymbol{\Delta})$ ). $(c)$ Oxygen-tolerant strains (Type II): BHT $(\triangle, \triangle)$; FAl $(O, O) ; 6715(\square, \square)$. 
Table 2. End products of mannitol fermentation by the eight strains of $S$. mutans under aerobic and anaerobic growth conditions

\begin{tabular}{|c|c|c|c|c|c|c|}
\hline \multirow[b]{2}{*}{ Type } & \multirow[b]{2}{*}{ Strain } & \multirow{2}{*}{$\begin{array}{l}\text { Growth } \\
\text { conditions }\end{array}$} & \multicolumn{4}{|c|}{ End products (\%) } \\
\hline & & & Lactate & Formate & Acetate* & Ethanol \\
\hline \multirow{6}{*}{$\begin{array}{l}\text { Oxygen- } \\
\text { sensitive }\end{array}$} & FIL & Aerobic & $89 \cdot 0$ & $1 \cdot 1$ & 9.9 & ND \\
\hline & FIL & Anaerobic & 11.8 & 40.9 & 3.8 & $44 \cdot 3$ \\
\hline & МТ8148 & Aerobic & $84 \cdot 4$ & ND & $15 \cdot 6$ & ND \\
\hline & MT8148 & Anaerobic & $3 \cdot 1$ & $36 \cdot 6$ & $12 \cdot 4$ & 47.9 \\
\hline & PK 1-M & Aerobic & $78 \cdot 3$ & $10 \cdot 4$ & $11 \cdot 3$ & ND \\
\hline & PK1-M & Anaerobic & $15 \cdot 5$ & $33 \cdot 1$ & 0.9 & $50 \cdot 5$ \\
\hline \multirow{10}{*}{$\begin{array}{c}\text { Oxygen- } \\
\text { tolerant }\end{array}$} & NCTC 10449 & Aerobic & 83.5 & $\begin{array}{r}2.7 \\
25.7\end{array}$ & $\begin{array}{r}13 \cdot 6 \\
2.8\end{array}$ & $\begin{array}{r}0 \cdot 2 \\
33.9\end{array}$ \\
\hline & NCTC 10449 & Anaerobic & 27.6 & $35 \cdot 7$ & $2 \cdot 8$ & 33.9 \\
\hline & PK 1-EB1 & Aerobic & $85 \cdot 4$ & $7 \cdot 0$ & 0.0 & $7 \cdot 6$ \\
\hline & PK 1-EB1 & Anaerobic & $20 \cdot 7$ & 41.8 & 0.0 & 37.5 \\
\hline & BHT & Aerobic & 87.4 & ND & $12 \cdot 6$ & ND \\
\hline & BHT & Anaerobic & 28.9 & $37 \cdot 4$ & $0 \cdot 3$ & $33 \cdot 4$ \\
\hline & $\mathrm{FAl}$ & Aerobic & 97.6 & ND & $2 \cdot 4$ & ND \\
\hline & FAl & Anaerobic & 24.9 & $31 \cdot 7$ & $19 \cdot 7$ & $23 \cdot 7$ \\
\hline & 6715 & Aerobic & $84 \cdot 7$ & 1.4 & $13 \cdot 7$ & $0 \cdot 2$ \\
\hline & 6715 & Anaerobic & 18.9 & $41 \cdot 7$ & $8 \cdot 3$ & $39 \cdot 1$ \\
\hline
\end{tabular}

ND, Not detected.

* The amount of acetate indicated has been corrected for the contaminating amount in TYM medium.

\section{Effect of aeration on the end products of mannitol metabolism}

Growth of the eight strains under aerobic conditions yielded lactate as the main product, whether or not oxygen suppressed growth, although strains FIL, MT8148 and PK 1-M produced lower concentrations of lactate, as expected from their poor growth. In contrast, anaerobic growth led to heterolactic fermentation which produced large amounts of ethanol and formate (Table 2). The proportion of ethanol to the total amount of the products formed varied markedly between oxygen-sensitive and oxygen-tolerant strains. The former, FIL, MT8148 and PK 1-M, gave a ratio of $44 \cdot 3,47.9$ and $50.5 \%$, respectively, while the latter gave a ratio of less than $40 \%$. Conversely, the proportion of lactate produced in oxygen-tolerant strains was higher than that in oxygen-sensitive strains. There was no significant difference in the amount of acetate produced between oxygen-sensitive and oxygen-tolerant strains.

The results indicated that oxygen changed mannitol catabolism in all strains examined from heterolactic to homolactic fermentation, and suggested that the observed difference in growth response to air depended on the activities of enzymes involved in mannitol metabolism and oxygen defence.

\section{Enzyme activities involved in mannitol catabolism}

The activities of several enzymes involved in mannitol catabolism were determined under aerobic and anaerobic conditions. A significantly high activity of pyruvate formate-lyase was demonstrated in extracts from anaerobically grown strains FIL, MT8148 and PK 1-M. In contrast, the enzyme activity in all oxygen-tolerant strains was low as compared with those in oxygen-sensitive strains. This was clearly correlated with the amounts of ethanol and formate produced by oxygen-sensitive strains under anaerobiosis. A positive correlation between the activity of this enzyme and growth rate was observed under anaerobic conditions except for strains BHT and FA1 (Fig. 2). The enzyme was not detected in extracts from aerobically grown cells of all strains. No correlation was found between growth rate and the activities of mannitol1-phosphate dehydrogenase, lactate dehydrogenase or alcohol dehydrogenase in extracts from any of the strains grown under either aerobic or strictly anaerobic conditions. 


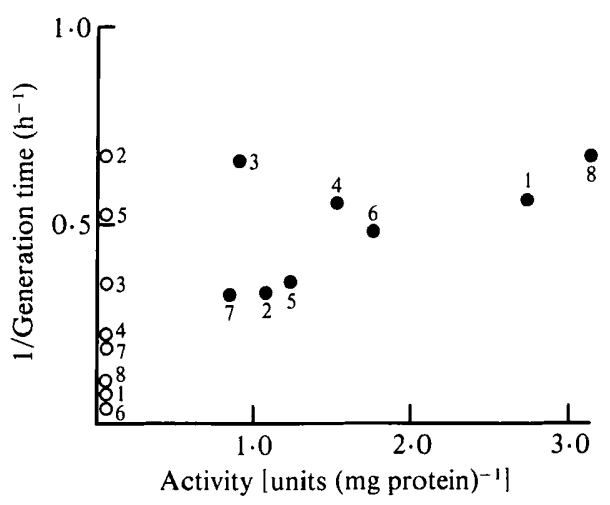

Fig. 2. Relation between growth rate and pyruvate formate-lyase activity in cell extracts. Cell extracts were prepared from cells grown to late-exponential phase on mannitol under aerobic $(O)$ and anaerobic (O) conditions, and pyruvate formate-lyase activity was determined as described in Methods. The enzyme activity of each strain was plotted against the reciprocal of the generation time. 1, FIL; 2, PK l-EB1; 3, BHT; 4, FA1; 5, NCTC 10449; 6, MT8148; 7, 6715; 8, PK 1-M.

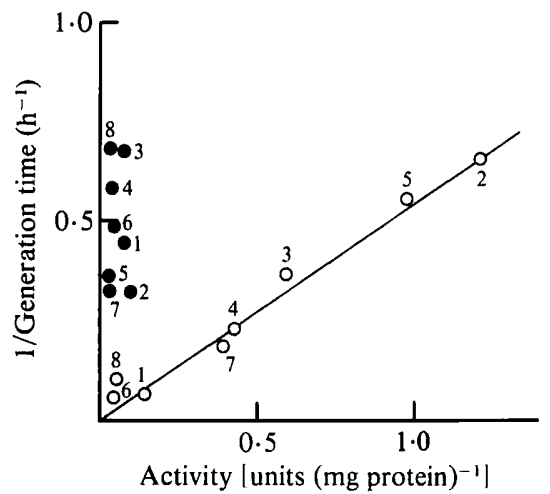

Fig. 3

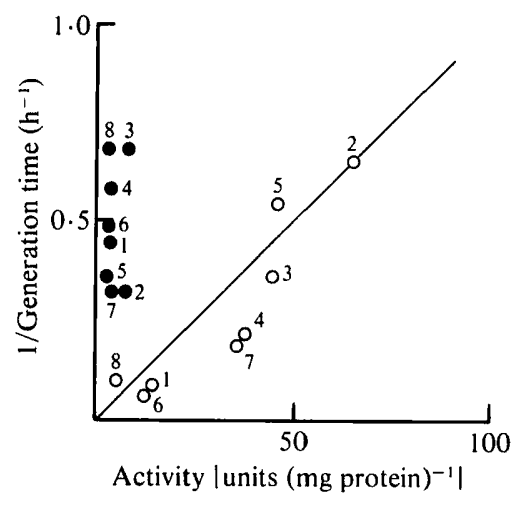

Fig. 4

Fig. 3. Correlation between growth rate and NADH oxidase activity in cell extracts. Cell extracts were prepared from cells grown to late-exponential phase on mannitol under aerobic $(O)$ and anaerobic $(O)$ conditions. NADH oxidase activity was determined as described in Methods. The enzyme activity of each strain was plotted against the reciprocal of the generation time. 1, FIL; 2, PK 1-EBI; 3, BHT; 4, FA1; 5, NCTC 10449; 6, MT8148; 7, 6715; 8, PK 1-M.

Fig. 4. Correlation between growth rate and superoxide dismutase activity in cell extracts. Cell extracts were prepared from cells grown to late-exponential phase on mannitol under aerobic $(O)$ and anaerobic (O) conditions, and superoxide dismutase activity was determined as described in Methods. The enzyme activity of each strain was plotted against the reciprocal of the generation time. 1, FIL; 2 , PK 1-EB1; 3, BHT; 4, FA1; 5, NCTC $10449 ; 6$, MT8148; 7, 6715; 8, PK 1-M.

\section{NADH oxidase activity in extracts}

The catabolism of mannitol differs from that of glucose by the production of an additional mole of NADH in the reaction converting mannitol 1-phosphate to fructose 6-phosphate (Brown \& Wittenberger, 1973). Under aerobic growth conditions, NADH is probably reoxidized by oxygen through NADH oxidase. To elucidate the nature of growth inhibition by oxygen, NADH oxidase activity in both oxygen-sensitive and oxygen-tolerant strains was determined. The results, summarized in Fig. 3, showed a clear correlation between NADH oxidase activity in cell extracts from aerobically grown cultures and their growth rate. The enzyme activity in extracts from oxygen-sensitive strains was lower than that from oxygentolerant strains. A significantly higher activity of NADH oxidase was detected in extracts from 
strains NCTC 10449 and PK 1-EB1. This corresponded to their faster growth rate under aerobic conditions. All strains exhibited low levels of enzyme activity $\left[<0 \cdot 1\right.$ units (mg protein) $\left.{ }^{-1}\right]$ when they were grown under strictly anaerobic conditions.

\section{Superoxidase dismutase activity in extracts}

The activity of superoxidase dismutase also correlated with growth rate under aerobic conditions (Fig. 4). The enzyme activity in the three oxygen-sensitive strains was as low as that detected in anaerobically grown cultures. In contrast, superoxide dismutase activity in the five oxygen-tolerant strains was high as compared with oxygen-sensitive strains.

\section{Effect of pyruvate and catalase on growth inhibition by oxygen}

To study the possibility that the mechanism of growth inhibition was by hydrogen peroxide produced under aerobic conditions, one of the oxygen-sensitive strains, PK 1-M, was grown aerobically on TYM medium supplemented with pyruvate (O'Brien \& Morris, 1971) or catalase, a scavenger of hydrogen peroxide. At a concentration of $18 \mathrm{~mm}$-pyruvate, growth inhibition by oxygen was still evident $\left(0.21 A_{660}\right.$ units at $\left.35 \mathrm{~h}\right)$, whereas both the growth rate and the cell yield ( $0.81 A_{660}$ units) increased as $25 \mathrm{~mm}$-pyruvate. However, at $50 \mathrm{~mm}$-pyruvate the growth rate was not affected but the cell yield was $0.53 A_{660}$ units. When catalase ( 3000 units $\mathrm{ml}^{-1}$ ) was added to the growth medium, no change in growth rate was observed, but the cell yield $\left(0 \cdot 26 A_{660}\right.$ units $)$ was slightly increased. The optimum concentration of pyruvate and catalase appeared to alleviate oxygen inhibition by about $51 \%$ and $4.0 \%$, respectively. Under these experimental conditions, the catalase added to the medium destroyed at least $0.48 \mu \mathrm{mol}$ hydrogen peroxide $\mathrm{min}^{-1} \mathrm{ml}^{-1}$. Therefore, these results suggest that hydrogen peroxide produced by PK $1-\mathrm{M}$ is not correlated with growth inhibition under aerobic conditions.

\section{Effect of oxygen on activities of NADH oxidase and superoxide dismutase}

After $2 \mathrm{~h}$ exposure to air, NADH oxidase activity in anaerobically grown strain NCTC 10449 increased 19-fold and superoxide dismutase activity increased 31-fold. However, no effect on NADH oxidase activity in strains FIL and MT8148 was detected by the treatment, whereas superoxide dismutase activity in these cultures increased 4- to 5.5-fold (Table 3 ). In these strains no induction of the enzymes was observed after $2 \mathrm{~h}$ anaerobic incubation at $35^{\circ} \mathrm{C}$.

Table 3. Induction of activities of NADH oxidase and superoxide dismutase in anaerobically grown bacteria by aeration

Two oxygen-sensitive strains (FIL and MT8148) and one oxygen-tolerant strain (NCTC 10449) were grown under anaerobic conditions to the mid-exponential phase $\left(0 \cdot 5 A_{660}\right.$ units). Then the bacteria were incubated under air at $35^{\circ} \mathrm{C}$ for $2 \mathrm{~h}$ with vigorous shaking before the assay as described in Methods.

\begin{tabular}{|c|c|c|c|}
\hline \multirow[b]{2}{*}{ Strain } & \multirow{2}{*}{$\begin{array}{l}\text { Time after } \\
\text { exposure } \\
\text { to air } \\
\text { (min) }\end{array}$} & \multicolumn{2}{|c|}{$\begin{array}{c}\text { Enzyme activity } \\
\text { [units (mg protein) }^{-1} \text { ] }\end{array}$} \\
\hline & & NADH oxidase & Superoxide dismutase \\
\hline NCTC 10449 & $\begin{array}{r}0 \\
30 \\
60 \\
120\end{array}$ & $\begin{array}{l}0.052 \\
0.275 \\
0.853 \\
0.985\end{array}$ & $\begin{array}{r}1 \cdot 6 \\
11 \cdot 7 \\
45 \cdot 5 \\
49 \cdot 6\end{array}$ \\
\hline FIL & $\begin{array}{r}0 \\
30 \\
60 \\
120\end{array}$ & $\begin{array}{l}0.050 \\
0.049 \\
0.064 \\
0.059\end{array}$ & $\begin{array}{l}1 \cdot 1 \\
2 \cdot 8 \\
4 \cdot 4 \\
3 \cdot 1\end{array}$ \\
\hline MT8148 & $\begin{array}{r}0 \\
30 \\
60 \\
120\end{array}$ & $\begin{array}{l}0.026 \\
0.022 \\
0.017 \\
0.016\end{array}$ & $\begin{array}{l}0 \cdot 9 \\
3 \cdot 7 \\
4 \cdot 8 \\
4 \cdot 5\end{array}$ \\
\hline
\end{tabular}




\section{DISCUSSION}

In the present study, three distinct patterns of growth and mannitol catabolism in response to aerobic and strictly anaerobic conditions were demonstrated among the eight strains of $S$. mutans. The growth of three strains, FIL, MT8148 and PK 1-M, (serotypes $a$ and $c$ ) was severely inhibited by oxygen, whereas the other (serotypes $b, c$ or $g$ ) behaved as oxygen-tolerant strains. The growth of two oxygen-tolerant strains (serotypes $b$ and $c$ ) was slightly enhanced by oxygen. These results indicated that oxygen-sensitivity of $S$. mutans strains is not a representative character distinguishing their serological group.

Three possibilities can be considered as the prime cause of the observed growth inhibition by oxygen: (1) oxygen acts as a toxic agent by producing superoxide radicals (O'Brien \& Morris, 1971; Fridovich, 1974; Lindmark \& Muller, 1974); (2) S. mutans, which lacks catalase, is inhibited by hydrogen peroxide (Anders et al., 1970); (3) oxygen inactivates key enzymes, which disturb energy metabolism (Abbe et al., 1982). The first possibility is supported by the observations that $(a)$ there is a good correlation between the activities of superoxide dismutase and NADH oxidase in the extracts and the growth rates of aerobically grown bacteria; and $(b)$ the activities of superoxide dismutase and NADH oxidase increase during aeration of anaerobically grown cells of oxygen-tolerant strains, but not in strains which are inhibited by oxygen.

It has been shown that $0.2 \mathrm{~mm}$-hydrogen peroxide inhibits the growth of Streptococcus cremoris by $50 \%$ (Anders et al., 1970), and also that some $S$. mutans strains release hydrogen peroxide in the presence of glucose, through a NADH-dependent reaction, while some strains excrete no hydrogen peroxide (Perch et al., 1974; Thomas \& Pera, 1983; Carlsson et al., 1983). However, the possibility of growth inhibition by hydrogen peroxide is negligible from the following observations: (a) catalase did not alleviate the growth inhibition; $(b)$ there were no significant differences in the amount of hydrogen peroxide produced by NADH oxidase in extracts of induced and uninduced cells of oxygen-sensitive strains. The alleviatory effect of pyruvate on growth inhibition remains to be elucidated.

The findings that oxygen affects mannitol catabolism by changing the fermentation end products and that no pyruvate formate-lyase activity was detected in cells grown under aerobic conditions support the third possibility. As mentioned before, under aerobic conditions the additional NADH produced in the reaction converting mannitol 1-phosphate to fructose 6phosphate is probably reoxidized by NADH oxidase. Consequently, aerobic catabolism of mannitol may depend on the level of NADH oxidase. In the present study, NADH oxidase activity in two oxygen-sensitive strains was not induced by oxygen but a slightly increased superoxide dismutase activity was observed in those strains (Table 3). Thus, we conclude that NADH oxidase activity in the cells is the most important factor in determining the oxygen-tolerance of $S$. mutans, though superoxide dismutase may also act as a defence mechanism against oxygen toxicity.

The author thanks Dr Y. Ozawa and Mrs K. Funada, Seishin Pharmaceutical Co., for their help in the analysis of carboxylic acids. She also thanks Dr S. Hamada, National Institute of Prevention and Hygiene, for his valuable advice and kind supply of $S$. mutans strains, and Emeritus Professor S. Araya, Tohoku University School of Dentistry, for his valuable discussions.

\section{REFERENCES}

Abbe, K., Takahashi, S. \& Yamada, T. (1982). Involvement of oxygen-sensitive pyruvate formatelyase in mixed acid fermentation of Streptococcus mutans under strictly anaerobic conditions. Journal of Bacteriology 152, 175-182.

ANDERs, R. F., HogG, D. M. \& JAGO, G. R. (1970). Formation of hydrogen peroxide by group $\mathrm{N}$ streptococci and its effect of their growth and metabolism. Applied Microbiology 19, 608-612.

Bratthall, D. (1969). Immunodiffusion studies on the serologic specificity of streptococci resembling Streptococcus mutans. Odontologisk Revy 20, 231243.
Brown, A. T. \& Patterson, C. E. (1973). Ethanol production and alcohol dehydrogenase activity in Streptococcus mutans. Archives of Oral Biology 18, 127-131.

Brown, A. T. \& Wittenberger, C. L. (1973). Mannitol and sorbitol catabolism in Streptococcus mutans. Archives of Oral Biology 18, 117-126.

Carlsson, J. (1967). Presence of various types of non-hemolytic streptococci in dental plaque, and other sites of the oral cavity. Odontologisk Revy 18, 55-74.

Carlsson, J., Iwami, Y. \& Yamada, T. (1983). Hydrogen peroxide excretion by oral streptococci and the 
effect of lactoperoxidase-thiocyanate-hydrogen peroxide. Infection and Immunity 40, 70-80.

CoYKendall, A. L. (1974). Four types of Streptococcus mutans based on their genetic, antigenic and biochemical characteristics. Journal of General Microbiology 83, 327-338.

Coykendall, A. L. (1977). Proposal to elevate the subspecies of Streptococcus mutans to species status, based on their molecular composition. International Journal of Systematic Bacteriology 27, 263-330.

EDWARDSSON, S. (1968). Characteristics of cariesinducing human streptococci resembling Streptococcus mutans. Archives of Oral Biology 13, 637646.

Fitzgerald, R. J., Jordan, H. V. \& Stanley, H. R. (1960). Experimental caries and gingival pathologic changes in the gnotobiotic rat. Journal of Dental Research 39, 923-935.

FrIDOVICH, I. (1974). Molecular mechanisms of oxygen activation. In Molecular Oxygen in Biology, Topics in Molecular Oxygen Research, pp. 453-477. Edited by O. Hayaishi, Amsterdam: Elsevier.

Gornall, A. G., Bardawill, C. S. \& David, M. M. (1949). Determination of serum proteins by means of the biuret reactions. Journal of Biological Chemistry 177, 751-757.

GugGenheim, B. (1968). Streptococci of dental plaque. Caries Research 2, 147-163.

Hamada, S., McGhee, J. R., Kyono, H., ToriI, M. \& MichaleK, S. M. (1981). Lymphoid cell responses to bacterial cell wall components: mitogenic responses of murine B cells to streptococcus carbohydrate antigens. Journal of Immunology 126, 2279-2283.

Higuchi, M., Endo, K., Hoshino, E. \& ARAya, S. (1973). Preferential induction of rough variants in Streptococcus mutans by ethidium bromide. Journal of Dental Research 52, 1070-1075.

Iacono, V. J., Taubman, M. A., Smith, D. J. \& Levine, M. J. (1975). Isolation and immunochemical characterization of the group-specific antigen of Streptococcus mutans 6715. Infection and Immunity 11,117128

Kasai, Y., Tanimura, T., Tamura, Z. \& Ozawa, Y. (1977). Automated determination of carboxylic acids by anion-exchange chromatography with specific colour reaction. Analytical Chemistry 49, 655-658.

Krasse, B., Jordan, H. V., EdWardsSon, S., SvensSON, O. \& TRELL, L. (1968). The occurrence of certain 'caries inducing' streptococci in human dental plaque material. Archives of Oral Biology 13, 911-918.

Lindmark, D. G. \& Muller, M. (1974). Superoxide dismutase in the anaerobic flagellates, Trichomonas foetus and Monocercomonas sp. Journal of Biological Chemistry 249, 4634-4637.

LipMaN, F. \& TUTTLE, L. C. (1945). A specific micromethod for the determination of acetylphosphate. Journal of Biological Chemistry 159, 21-28.

MisRA, H. P. \& FrIDovich, I. (1976). A convenient calibration of the Clark oxygen electrode. Analytical Biochemistry 70, 632-634.

O'Brien, R. W. \& Morris, J. G. (1971). Oxygen and the growth and metabolism of Clostridium acetobutylicum. Journal of General Microbiology 68, 307318.

PerCh, B., KJems, E. \& Ravn, T. (1974). Biochemical and serological properties of Streptococcus mutans from various human and animal sources. Acta pathologica et microbiologica scandinavica, B82, 357378.

Sawicki, I., Stanley, T. W., Pfaff, J. \& Ferguson, J. (1961). New methods for the spot test detections and spectrophotometric determination of formic acid. In Analytical Chemistry, Proceedings of International Symposium, pp. 62-65. Birmingham: University of Birmingham.

Shklair, I. L., KeEne, H. J. \& Simonson, L. S. (1972). Distribution and frequency of Streptococcus mutans in caries-active individuals. Journal of Dental Research 51, 882.

Thomas, E. L. \& Pera, K. A. (1983). Oxygen metabolism of Streptococcus mutans: uptake of oxygen and release of superoxide and hydrogen peroxide. Journal of Bacteriology 154, 1236-1244.

Vance, G. P. \& Keele, B. B., JR. (1972). Superoxide dismutase from Streptococcus mutans. Journal of Biological Chemistry 1247, 4782-4786.

Woods, R. (1971). A dental caries susceptibility test based on the occurrence of Streptococcus mutans in plaque material. Australian Dental Journal 16, 116121.

Yamada, T. \& CARlsson, J. (1976). The role of pyruvate formate-lyase in glucose metabolism of Streptococcus mutans. In Proceedings of Microbial Aspects of Dental Caries (Special Supplement to Microbiology Abstracts, vol. 3), pp. 809-819. Edited by H. M. Stiles, W. J. Loesche \& T. C. O'Brien. Washington, DC: Information Retrieval Inc.

Yamada, T., ENDO, K. \& ARAYA, S. (1976). A fructose 1,6-diphosphate-independent L-lactate dehydrogenase in a strain of Streptococcus mutans. Archives of Oral Biology 21, 233-236.

ZINNER, D. D. \& JABLON, J. M. (1968). Human streptococcal strains in experimental caries. In Art and Science of Dental Caries Research, pp. 87-109. Edited by R.S. Harris. New York: Academic Press. 